\title{
OPTIMASI PROSES EKSTRAKSI ASAM FERULAT SECARA ALKALI DARI SERAT MESOKARP SAWIT MENGGUNAKAN METODE PERMUKAAN RESPON
}

\author{
Optimization of Ferulic Acid Alkaline Extraction Process from Palm Mesocarp Fiber \\ using Response Surface Methodology
}

\author{
Sukma Budi Ariyani, Mohamad Rusdi Hidayat ${ }^{\star}$, Haqqifizta Ratihwulan, Agus Sri Mulyono \\ Balai Riset dan Standardisasi Industri Pontianak-Kementerian Perindustrian, \\ JIn. Budi Utomo No. 41 Pontianak 78243, Indonesia \\ *e-mail: mr-hidayat@kemenperin.go.id
}

\begin{abstract}
As the palm oil industry in Indonesia increases, so does the amount of waste generated. Palm mesocarp fiber is one of the solid wastes produced by the crude palm oil industry which has high lignin content. One of the phenolic compounds bound with lignin is ferulic acid. Ferulic acid is a fine chemical that widely used in various industries such as pharmaceuticals, cosmetics, and foods. This study aims to determine the effect of $\mathrm{NaOH}$ concentration $\left(X_{1}\right)$, immersion time in $\mathrm{NaOH}\left(X_{2}\right)$, and sterilization time in the autoclave $\left(X_{3}\right)$ on ferulic acid content obtained in the alkali extraction process from palm mesocarp fibers using the surface response methodology (RSM). The regression equation obtained is: $Y=$ $38.87-28.8\left(X_{1}\right)-1.69\left(X_{2}\right)-1.741\left(X_{3}\right)+0.385\left(X_{2}^{2}\right)-0.20\left(X_{1} X_{2}\right)+2.078\left(X_{1} X_{3}\right)+0.0276\left(X_{2} X_{3}\right)$. The optimal condition prediction results obtained were the autoclaving time at 30 minutes, 1 $\mathrm{M} \mathrm{NaOH}$ concentration, and 9 hours soaking time result in $41.84 \mathrm{mg} / \mathrm{L}$ of ferulic acid. Validation results from the optimal conditions produced $46.45 \mathrm{mg} / \mathrm{L}$ of ferulic acid.
\end{abstract}

Keywords: Alkaline extraction, ferulic acid, palm mesocarp fiber, RSM

\begin{abstract}
Abstrak: Seiring dengan meningkatnya industri minyak sawit di Indonesia, meningkat pula jumlah limbah yang dihasilkan. Serat mesokarp sawit merupakan salah satu limbah padat berlignin tinggi yang dihasilkan oleh industri ini. Salah satu senyawa fenolik yang terikat dengan lignin adalah asam ferulat. Asam ferulat bernilai tinggi karena banyak digunakan di berbagai industri seperti farmasi, kosmetik, hingga makanan. Penelitian ini bertujuan mengetahui pengaruh konsentrasi $\mathrm{NaOH}(X 1)$, waktu perendaman di dalam $\mathrm{NaOH}$ (X2) dan waktu saat autoklaf (X3) terhadap respon berupa kadar asam ferulat yang diperoleh pada proses ekstraksi alkali dari serat mesokarp sawit menggunakan metode permukaan respon (RSM). Persamaan model regresi yang diperoleh adalah : $Y=38,87-28,8(X 1)-1,69(X 2)-$ $1,741(X 3)+0,385(X 22)-0,20(X 1 X 2)+2,078(X 1 X 3)+0,0276(X 2 X 3)$. Hasil prediksi kondisi optimal yang diperoleh adalah pada variabel waktu autoklaf 30 menit, konsentrasi $\mathrm{NaOH} 1$ $M$ dan waktu perendaman 9 jam dengan menghasilkan respon asam ferulat sebesar 41,84 $\mathrm{mg} / \mathrm{L}$. Berdasarkan hasil validasi, pada kondisi optimal tersebut menghasilkan asam ferulat sebesar 46,45 $\mathrm{mg} / \mathrm{L}$.
\end{abstract}

Kata kunci: Asam ferulat, ekstraksi alkali, serat mesokarp sawit, RSM

\section{PENDAHULUAN}

Indonesia merupakan negara produsen minyak sawit terbesar di dunia dengan total produksi sebesar 42,04 juta ton pada tahun 2017. Produksi minyak sawit (CPO) dari tahun 2014 sampai dengan 2018 selalu mengalami peningkatan dengan kisaran antara 1,35 sampai dengan 10,96\%. Pada tahun 2014 produksi minyak sawit (CPO) sebesar 29,28 juta ton, meningkat menjadi 34,94 juta ton pada tahun 2017 atau terjadi peningkatan sebesar $19,34 \%$. Sementara tahun 2018 diperkirakan produksi minyak sawit (CPO) akan meningkat menjadi
36,59 juta ton atau sebesar 4,74\% (Badan Pusat Statistik, 2018). Sebanyak $60 \%$ dari produksi CPO Indonesia diekspor dan sisanya untuk konsumsi dalam negeri (Indonesia Eximbank, 2018).

Peningkatan produksi CPO tersebut tentu akan meningkatkan jumlah limbah yang dihasilkan pada proses produksi. Limbah kelapa sawit adalah sisa-sisa hasil tanaman kelapa sawit yang tidak termasuk dalam produk utama atau merupakan hasil ikutan dari proses pengolahan kelapa sawit baik berupa 
limbah padat maupun limbah cair (Silalahi \& Suprijatno, 2017). Berdasarkan persentase berat limbah, pabrik kelapa sawit menghasilkan limbah padat berupa: tandan kosong (22\%) dari porsi tandan buah segar (TBS), serat mesokarp (13\%), cangkang $(4,5 \%)$, abu $(0,01 \%)$, dan limbah cair ( $p a l m$ oil mill effluent, POME) sekitar 0,62-0,77 $\mathrm{m}^{3} /$ ton TBS (Santoso, 2018).

Mesokarp merupakan daging buah yang berserabut. Serat mesokarp sawit (Gambar 1) yang disebut sabut atau serabut sawit (mesocarp fiber) adalah serat yang terdapat pada daging buah kelapa sawit yang merupakan bahan alam berbentuk serabut panjang antara 3$4 \mathrm{~cm}$. Pemanfaatan dari serat mesokarp kelapa sawit dapat berguna untuk papan pengisi tripleks, kayu lapis, meja datar, plat serat, dan sebagainya (Haryanti et al., 2014, Rahmasita et al., 2017, dan Rahardja, 2017). Susilo (2017) menyebutkan bahwa serat mesokarp sawit mengandung senyawa selulosa sebesar $41,92 \%$; lignin $21,71 \%$; dan hemiselulosa 11,36.

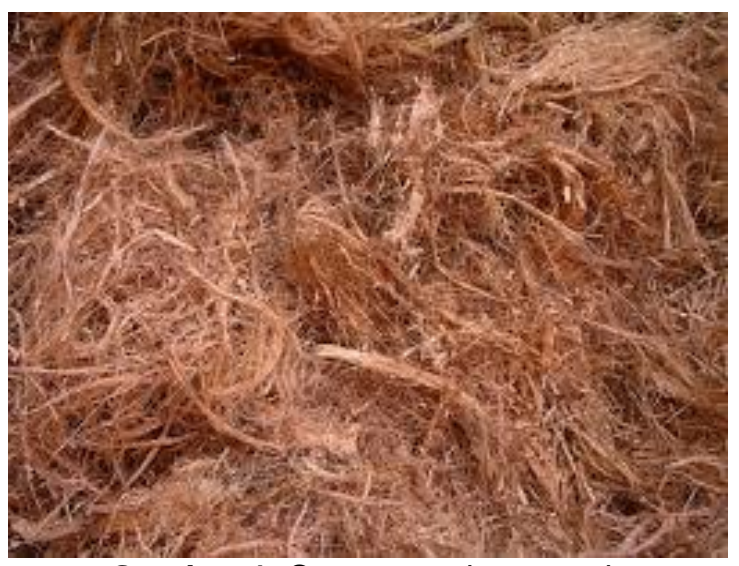

Gambar 1. Serat mesokarp sawit

Lignin adalah salah satu komponen penyusun tanaman yang bersama dengan selulosa dan bahan-bahan serat lainnya membentuk bagian struktural dan sel tumbuhan. Pada batang tanaman, lignin berfungsi sebagai bahan pengikat komponen penyusun lainnya, sehingga suatu pohon bisa berdiri tegak. Berbeda dengan selulosa yang terutama terbentuk dari gugus karbohidrat, lignin terbentuk dan gugus aromatik yang saling dihubungkan dengan rantai alifatik, yang terdiri dari 2-3 karbon. Pada proses pirolisis lignin, dihasilkan senyawa kimia aromatis yang berupa fenol (Hadrawi, 2014). Lignin merupakan polimer berkadar fenolik tinggi, berwarna kecoklatan, dan relatif mudah teroksidasi.

Asam ferulat merupakan salah satu jenis asam fenolat yang terkandung dalam tanaman yang berasal dari metabolisme fenilalanin dan tirosin. Asam ferulat banyak ditemukan pada biji dan daun dalam bentuk bebas dan terikat dengan lignin dan biopolimer lainnya (Listyo et al., 2018).

Asam ferulat adalah antioksidan fenolik yang terdapat dalam tanaman, yang banyak digunakan dalam industri makanan dan kosmetik (Tilay et al., 2008). Selain itu juga senyawa turunan asam ferulat pun memiliki aktivitas biologi sebagai antivirus dan insektisida (Sultan \& Soekamto, 2017).

Asam ferulat teresterifikasi telah berhasil diekstrak dari berbagai limbah pertanian seperti dedak jagung, dedak padi, dedak gandum, jerami gandum, gula tebu, kulit nanas, kulit jeruk, dan kulit buah delima (Tilay et al., 2008). Pada penelitian ini digunakan limbah serat mesokarp sawit sebagai substrat untuk proses ekstraksi asam ferulat secara alkali hingga diperoleh kondisi optimum menggunakan metode permukaan respon.

Metode permukaan respon (response surface methodology) merupakan suatu strategi percobaan yang berguna jika respon dipengaruhi beberapa faktor dan tujuan percobaan adalah untuk mencari respon optimum (Trihaditia, 2015). Ratnawati et al. (2018) juga menyebutkan metode ini merupakan metode statistika yang menganalisis pengaruh variabel bebas terhadap variabel respon dengan tujuan mengoptimalkan respon. Keunggulan metode RSM ini tidak memerlukan datadata percobaan dalam jumlah yang besar dan tidak membutuhkan waktu lama (Nurmiah et al., 2013). 
Penelitian ini bertujuan untuk mengekstraksi asam ferulat secara alkali dari limbah serat mesokarp sawit dan mengetahui pengaruh pretreatment fisika (waktu autoklaf), konsentrasi $\mathrm{NaOH}$, dan suhu perendaman terhadap kadar asam ferulat yang diekstraksi dari serat mesokarp sawit menggunakan metode permukaan respon (RSM). Selain itu, penelitian ini juga bertujuan untuk memperoleh kondisi proses yang optimal pada proses ekstraksi asam ferulat dari limbah serat mesokarp sawit berdasarkan RSM.

\section{METODOLOGI \\ Bahan dan Alat}

Bahan utama yang digunakan adalah serat mesokarp sawit, $\mathrm{NaOH}, \mathrm{HCl}$ dan akuades. Sedangkan alat utama yang digunakan adalah sentrifuse Sorvall ${ }^{\mathrm{TM}}$ Legend $^{\mathrm{TM}}$ Micro 17 (Thermo Scientific ${ }^{\mathrm{TM}}$ ) dan HPLC Perkin Elmer Series 200 Autosampler.

\section{Penepungan serat mesokarp sawit}

Serat mesokarp sawit yang diperoleh dari pabrik terlebih dahulu dicuci dan dibersihkan dengan air bersih untuk menghilangkan tanah dan bahan pencemar lainnya. Serat yang telah bersih selanjutnya dikeringkan pada suhu $60 \stackrel{\circ}{ } \mathrm{C}$ selama 2 hari. Selanjutnya serat dihaluskan dengan mesin penepung dan diayak dengan saringan 40 mesh untuk mendapatkan ukuran yang seragam. Tepung serat mesokarp yang diperoleh digunakan sebagai substrat untuk ekstraksi asam ferulat.

\section{Ekstraksi asam ferulat menggunakan metode alkali}

Variabel berubah yang digunakan adalah waktu autoklaf bahan, konsentrasi alkali $(\mathrm{NaOH})$ dan lama waktu perendaman dalam larutan $\mathrm{NaOH}$. Ekstraksi asam ferulat dengan metode alkali yang digunakan pada penelitian ini merupakan modifikasi metode dari Aanifah et al. (2014). Perbedaannya terdapat pada bahan utama yang digunakan tetapi variabel berubah yang digunakan sama. Pada penelitian Aanifah et al. (2014) bahan utama yang digunakan adalah serat tandan kosong kelapa sawit sedangkan pada penelitian ini menggunakan bahan utama serat mesokarp sawit.

Pada metode ini, tepung serat mesokarp sawit di autoklaf $121^{\circ} \mathrm{C}$ pada 1 atm, dengan waktu sesuai variabel. Sebanyak $10 \% \quad(b / v)$ serat mesokarp sawit selanjutnya direndam dalam larutan $\mathrm{NaOH}$ dengan konsentrasi sesuai variabel sambil dipanaskan pada suhu 90 ○C menggunakan magnetic stirrer dengan waktu sesuai variabel.

Hidrolisat yang diperoleh kemudian diubah pHnya menjadi 2 dengan $\mathrm{HCl}$ dan disentrifuse pada $12.000 \mathrm{rpm}$ selama 10 menit. Supernatan yang diperoleh kemudian diukur kadar asam ferulatnya dengan HPLC.

\section{Analisis HPLC}

Preparasi sampel untuk pengukuran menggunakan HPLC dilakukan dengan cara disentrifugasi pada $12.000 \mathrm{rpm}$ selama 10 menit. Pengukuran kadar asam ferulat merupakan modifikasi metode yang dilakukan oleh Muchuweti et al. (2005). Proses pemisahan dilakukan menggunakan HPLC Perkin Elmer with autosampler dengan kolom C18, dan UV detector pada $280 \mathrm{~nm}$. Fase gerak air:metanol (75:25) dengan laju alir 1 $\mathrm{mL} / \mathrm{min}$. Kuantifikasi berbagai senyawa tersebut dilakukan dengan menggunakan standar eksternal.

\section{Analisis Data Menggunakan RSM}

Penentuan kondisi proses terbaik ekstraksi asam ferulat dari serat mesokarp sawit menggunakan Central Composite Design (CCD). Penelitian dilakukan menggunakan tiga faktor yaitu konsentrasi $\mathrm{NaOH} \quad\left(\mathrm{X}_{1}\right)$, waktu perendaman di dalam $\mathrm{NaOH}\left(\mathrm{X}_{2}\right)$ dan waktu saat autoklaf $\left(X_{3}\right)$. Rentang konsentrasi $\mathrm{NaOH}$ yang digunakan adalah 0,5-1 $\mathrm{M}$, waktu perendaman di dalam $\mathrm{NaOH}$ adalah 0-9 jam dan waktu autoklaf 0-30 menit. Penentuan rentang variabel bebas diperoleh dari kajian penelitian sebelumnya dan trial error. Nilai batas mínimum dan maksimum tersebut 
dimasukkan ke dalam program untuk dilakukan pengacakan kombinasi sehingga didapatkan rancangan formula yang akan dianalisis sebanyak 22 formula percobaan (Tabel 1). Respon yang dianalisis pada penelitian ini adalah jumlah asam ferulat (Y). Pengolahan data ini menggunakan software Minitab 19. Optimasi dengan metode RSM memberikan keuntungan yakni dapat menghemat biaya dan waktu karena banyaknya percobaan yang dilakukan berdasarkan rancangan percobaan yang keluar pada program yakni pada penelitian ini sebanyak 22 formula percobaan.

Tabel 1. Rancangan Percobaan CCD untuk ekstraksi asam ferulat

\begin{tabular}{|c|c|c|c|c|}
\hline \multirow[b]{2}{*}{ Run } & \multicolumn{3}{|c|}{ Faktor } & \multirow[b]{2}{*}{$\begin{array}{c}\text { Asam Ferulat } \\
(\mathrm{mg} / \mathrm{L}) \\
(\mathrm{Y})\end{array}$} \\
\hline & $\begin{array}{c}\mathrm{NaOH}(\mathrm{M}) \\
\left(\mathrm{X}_{1}\right)\end{array}$ & $\begin{array}{c}\text { Waktu } \\
\text { Perendaman (Jam) } \\
\left(\mathrm{X}_{2}\right) \\
\end{array}$ & $\begin{array}{c}\text { Waktu Autoklaf } \\
\text { (Menit) } \\
\left(\mathrm{X}_{3}\right) \\
\end{array}$ & \\
\hline 1 & 1 & 9 & 30 & 46,393 \\
\hline 2 & 0,5 & 9 & 30 & 21,882 \\
\hline 3 & 0,5 & 0 & 0 & 19,702 \\
\hline 4 & 1 & 0 & 30 & 10,802 \\
\hline 5 & 0,5 & 9 & 0 & 46,799 \\
\hline 6 & 1 & 9 & 0 & 17,867 \\
\hline 7 & 0,5 & 0 & 30 & 8,266 \\
\hline 8 & 1 & 6 & 15 & 13,223 \\
\hline 9 & 1 & 3 & 15 & 18,791 \\
\hline 10 & 0,5 & 6 & 15 & 13,949 \\
\hline 11 & 1 & 0 & 0 & 13,631 \\
\hline 12 & 0,5 & 9 & 30 & 22,746 \\
\hline 13 & 1 & 9 & 0 & 19,093 \\
\hline 14 & 0,5 & 0 & 30 & 10,539 \\
\hline 15 & 1 & 0 & 0 & 13,408 \\
\hline 16 & 0,5 & 6 & 15 & 15,795 \\
\hline 17 & 0,5 & 0 & 0 & 20,387 \\
\hline 18 & 0,5 & 9 & 0 & 45,868 \\
\hline 19 & 1 & 9 & 30 & 46,562 \\
\hline 20 & 1 & 6 & 15 & 24,600 \\
\hline 21 & 1 & 0 & 30 & 15,629 \\
\hline 22 & 1 & 3 & 15 & 21,388 \\
\hline
\end{tabular}

\section{HASIL DAN PEMBAHASAN}

Keberhasilan proses ekstraksi asam ferulat dari berbagai sumber biomassa pertanian yang mengandung selulosa, hemiselulosa, dan lignin dipengaruhi oleh perlakuan konsentrasi alkali, suhu, dan waktu pemanasan (Tilay et al., 2008 dan Aarabi et al., 2016). Aanifah et al. (2014) membandingkan beberapa desain ekstraksi asam ferulat pada serat tandan kosong kelapa sawit (TKKS) dengan mempertimbangkan perlakuan autoklaf sebagai proses termal. Perlakuan autoklaf pre-ekstraksi serat TKKS terindikasi dapat mempengaruhi pelepasan asam ferulat karena degradasi asam ferulat akibat suhu panas $121{ }^{\circ} \mathrm{C}$ dan tekanan pada autoklaf. 
Hasil analisis koefisien dan nilai $P$ dengan software Minitab 19 menunjukkan bahwa yang berpengaruh signifikan terhadap ekstraksi asam ferulat adalah variabel waktu perendaman di dalam $\mathrm{NaOH}$ dan interaksi antara variabel konsentrasi $\mathrm{NaOH}$ dan waktu autoklaf karena memiliki nilai $\mathrm{P}<0,05$ yakni 0,000 dan 0,000 (Tabel 2). Sedangkan untuk variabel dan interaksi antar variabel lainnya tidak berpengaruh signifikan karena memiliki nilai $P>0,05$. Waktu perendaman di dalam $\mathrm{NaOH}$ berpengaruh signifikan dalam proses ekstraksi ini. Hal ini diduga disebabkan karena adanya peningkatan reaksi antara komponen yang diekstrak dengan $\mathrm{NaOH}$ yang digunakan sehingga dapat melepaskan asam ferulat lebih banyak (Aarabi et al., 2016). Selain itu, $\mathrm{NaOH}$ merupakan jenis basa yang digunakan sebagai katalis dalam hidrolisis. Sifat $\mathrm{NaOH}$ sebagai basa mampu melarutkan lignin dengan memotong rantai ester pada kompleks lignin-polisakarida yang menyebabkan pelepasan dan larutnya komponen fenolik. Kelebihan sifat $\mathrm{NaOH}$ dibandingkan jenis basa lain adalah memiliki kemampuan selektif dalam melepaskan komponen fenolik termasuk FA (Aarabi et al., 2016).

Tabel 2. Koefisien dan Nilai P Variabel Bebas

\begin{tabular}{lccc}
\hline \multicolumn{1}{c}{ Kondisi } & Koefisien & Nilai T & Nilai P \\
\hline Constant & 15,92 & 4,97 & 0,000 \\
$\mathrm{NaOH}$ & 0,37 & 0,25 & 0,808 \\
Waktu Perendaman & 9,18 & 5,43 & 0,000 \\
Waktu Autoklaf & $-0,87$ & $-0,51$ & 0,621 \\
Waktu Perendaman*Waktu Perendaman & 7,80 & 2,07 & 0,057 \\
$\mathrm{NaOH}^{*}$ Waktu Perendaman & $-0,23$ & $-0,13$ & 0,896 \\
$\mathrm{NaOH}^{*}$ Waktu Autoklaf & 7,79 & 4,53 & 0,000 \\
Waktu Perendaman*Waktu Autoklaf & 1,87 & 1,08 & 0,297 \\
\hline
\end{tabular}

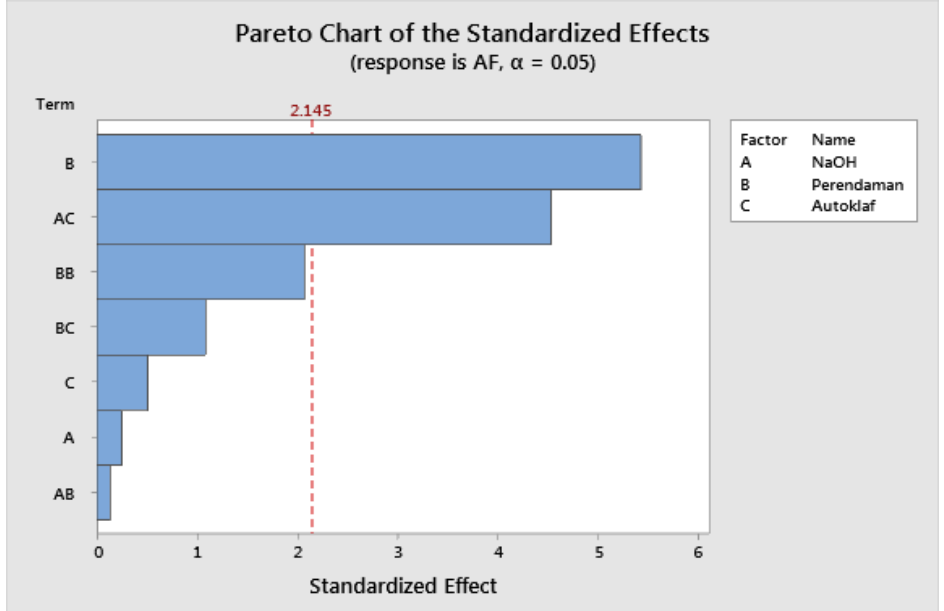

Gambar 2. Diagram Pareto pengaruh konsentrasi $\mathrm{NaOH}$, waktu perendaman dalam $\mathrm{NaOH}$ dan waktu autoklaf terhadap kadar asam ferulat

Melalui Diagram Pareto dapat pada diagram menunjukkan posisi $\alpha=$ diketahui berbagai variabel yang 0,05 (Hasibuan, 2017). Variabel yang berpengaruh secara signifikan terhadap berada di sebelah kiri base line kadar asam ferulat (Gambar 2). Base line menunjukkan bahwa variabel tersebut 
tidak berpengaruh secara signifikan terhadap kadar asam ferulat yang diperoleh. Berdasarkan analisis ragam, pada model di atas menghasilkan nilai $P$ sebesar 0,001 artinya nilai $P$ yang diperoleh lebih kecil dari taraf signifikansi yang digunakan yaitu sebesar $\alpha=0.05$ (Tabel 3). Nilai $\mathrm{P}<0,05$ artinya bahwa variabel bebas memberikan pengaruh signifikan terhadap variabel respon (Deswati et al., 2015), sehingga model tersebut dapat diterima. Persamaan model regresi yang diperoleh adalah:

$Y=38,87-28,8\left(X_{1}\right)-1,69\left(X_{2}\right)-$ $1,741\left(X_{3}\right)+0,385\left(X_{2}^{2}\right)-0,20\left(X_{1} X_{2}\right)+$ $2,078\left(X_{1} X_{3}\right)+0,0276\left(X_{2} X_{3}\right)$

Tabel 3. Analisa Ragam Asam Ferulat Hasil Ekstraksi

\begin{tabular}{lcrrrr}
\hline \multicolumn{1}{c}{ Sumber } & DF & Adj SS & Adj MS & Nilai F & Nilai P \\
\hline Model & 7 & 2580,98 & 368,71 & 7,79 & 0,001 \\
Linier & 3 & 1408,19 & 469,40 & 9,91 & 0,001 \\
$\quad$ NaOH & 1 & 2,92 & 2,92 & 0,06 & 0,808 \\
$\quad$ Waktu Perendaman & 1 & 1396,05 & 1396,05 & 29,48 & 0,000 \\
$\quad$ Waktu Autoklaf & 1 & 12,14 & 12,14 & 0,26 & 0,621 \\
Square & 1 & 203,51 & 203,51 & 4,30 & 0,057 \\
$\quad$ Waktu Perendaman*Waktu & 1 & 203,51 & 203,51 & 4,30 & 0,057 \\
$\quad$ Perendaman & 3 & 1028,54 & 342,85 & 7,24 & 0,004 \\
Interaksi Dua Arah & 1 & 0,84 & 0,84 & 0,02 & 0,896 \\
$\quad$ NaOH*Waktu Perendaman & 1 & 972,02 & 972,02 & 20,52 & 0,000 \\
$\quad$ NaOH*Waktu Autoklaf & 1 & 55,68 & 55,68 & 1,18 & 0,297 \\
$\quad$ Waktu Perendaman*Waktu & 14 & 663,06 & 192,40 & & \\
$\quad$ Autoklaf & 3 & 577,20 & 7,81 & 24,65 & 0,000 \\
Error & 11 & 85,86 & & & \\
Lack-of-Fit & 21 & 3244,03 & & & \\
$\quad$ Pure Error & & & & & \\
Total & & &
\end{tabular}

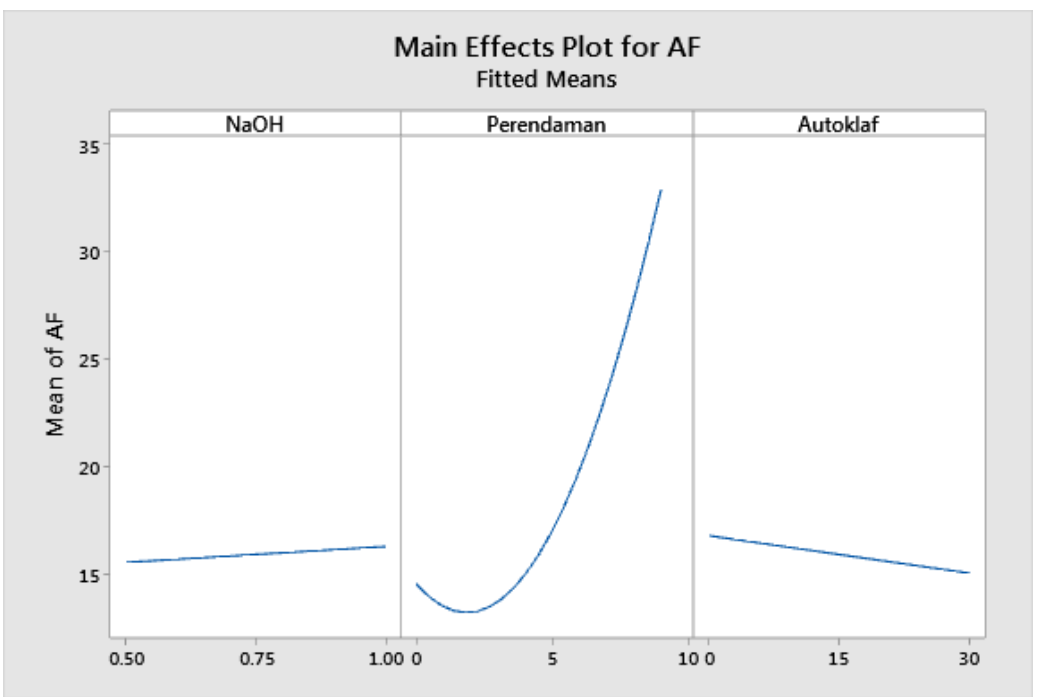

Gambar 3. Grafik Main Effects Plot kadar asam ferulat

Grafik main effect plot faktor terhadap kadar asam ferulat yang memperlihatkan pengaruh masing-masing diperoleh (Gambar 3). Kadar asam ferulat 
terendah pada masing-masing grafik diperoleh pada konsentrasi $\mathrm{NaOH}$ yang digunakan 0,5 $\mathrm{M}$, waktu perendaman 2,5 jam dan waktu autoklaf 30 menit. Sedangkan kadar asam ferulat tertinggi pada masing-masing grafik diperoleh pada konsentrasi $\mathrm{NaOH} 1 \mathrm{M}$, waktu perendaman 9 jam dan waktu autoklaf 0 menit. Penelitian ini mencoba menentukan tiga faktor yang berpengaruh dalam proses ekstraksi asam ferulat, maka terdapat 3 grafik permukaan respon dan kontur plot untuk menjelaskan pengaruh interaksi antar variabel. Berbagai interaksi antar faktor tersebut dijelaskan di bawah ini.

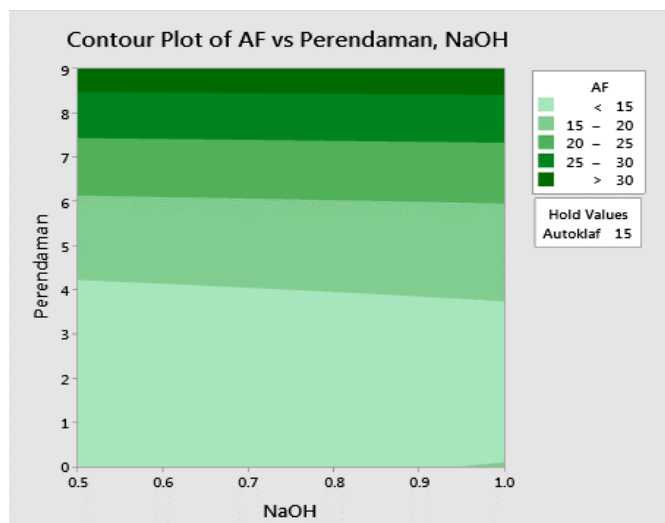

Pengaruh Konsentrasi $\mathrm{NaOH}$ dan Waktu Perendaman terhadap Kadar Asam Ferulat

Hubungan antara konsentrasi $\mathrm{NaOH}$ dan waktu perendaman terhadap kadar asam ferulat yang dihasilkan pada contour plot dan surface plot menunjukkan bahwa semakin lama perendaman maka semakin tinggi respon asam ferulat yang berhasil diekstraksi. Konsentrasi $\mathrm{NaOH}$ yang digunakan hanya sedikit berpengaruh terhadap respon, dengan kecenderungan semakin tinggi konsentrasi $\mathrm{NaOH}$ yang digunakan maka semakin kecil respon yang dihasilkan (Gambar 4).

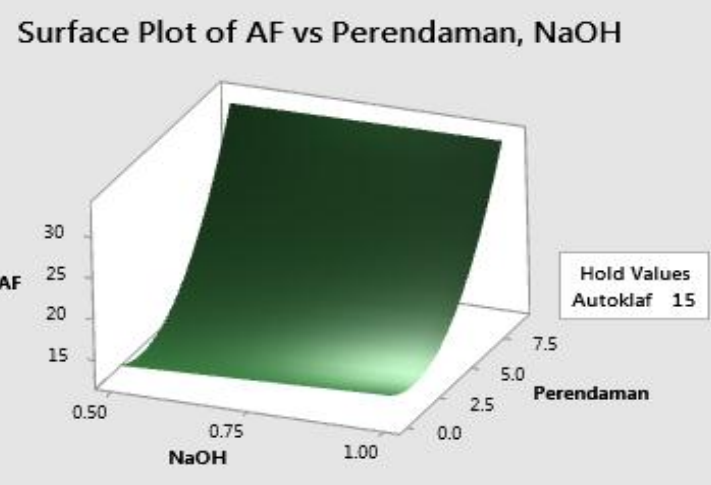

Gambar 4. Contour plot dan surface plot dari kadar asam ferulat, konsentrasi $\mathrm{NaOH}$ dan waktu perendaman

Untuk memperoleh kadar asam ferulat tinggi, diperlukan konsentrasi $\mathrm{NaOH}$ (alkali yang digunakan) yang rendah. Hal ini disebabkan karena dengan konsentrasi alkali yang tinggi akan mendegradasi lignin (delignifikasi) pada bahan. Sedangkan pelepasan asam ferulat tersebut berasal dari lignin. Oleh karena itu jika lignin dalam bahan semakin kecil maka kadar asam ferulat yang dihasilkan akan semakin kecil pula (Aanifah et al., 2014).

\section{Pengaruh Konsentrasi $\mathrm{NaOH}$ dan Waktu Autoklaf terhadap Kadar Asam Ferulat}

Hubungan antara konsentrasi $\mathrm{NaOH}$ dan waktu autoklaf terhadap respon kadar asam ferulat yang dihasilkan pada contour plot dan surface plot (Gambar 5) menunjukkan bahwa semakin kecil konsentrasi $\mathrm{NaOH}$ yang digunakan dengan waktu autoklaf yang semakin kecil menghasilkan respon kadar asam ferulat yang semakin tinggi. Kadar asam ferulat yang tinggi juga diperoleh bila $\mathrm{NaOH}$ yang digunakan $1 \mathrm{M}$ dengan meningkatkan waktu autoklaf menjadi 30 menit. 

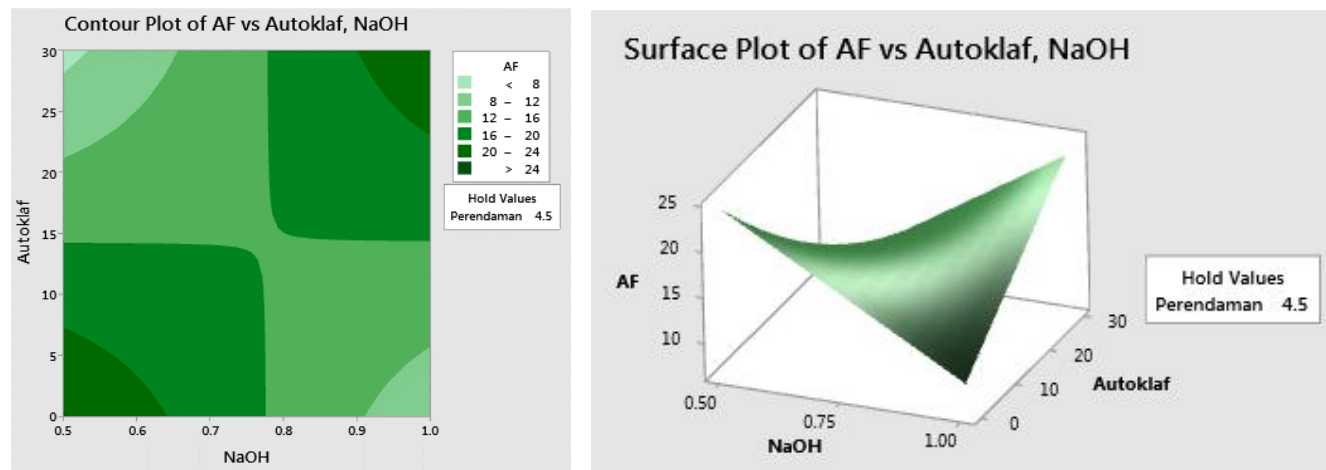

Gambar 5. Contour plot dan surface plot dari kadar asam ferulat, konsentrasi $\mathrm{NaOH}$ dan waktu autoklaf

Perlakuan autoklaf diduga mampu mendukung ekstraksi asam ferulat karena proses termal membantu menghancurkan dinding sel (Aanifah et al., 2014). Tetapi menurut Nasruddin, 2012 bahwa semakin lama proses sterilisasi (autoklaf), kandungan lignin dalam suatu bahan menjadi semakin berkurang. Dengan berkurangnya lignin maka pelepasan asam ferulat menjadi berkurang. Hal tersebut yang mengakibatkan kadar asam ferulat yang diperoleh semakin kecil seiring dengan semakin lama waktu autoklaf.

\section{Pengaruh Waktu Perendaman dan Waktu Autoclave terhadap Kadar Asam Ferulat}

Hubungan antara waktu perendaman di dalam $\mathrm{NaOH}$ dan waktu autoklaf terhadap respon kadar asam ferulat yang dihasilkan pada contour plot dan surface plot (Gambar 6) menunjukkan bahwa semakin lama waktu perendaman dan waktu autoklaf yang semakin sebentar menghasilkan respon kadar asam ferulat yang semakin tinggi. Kadar asam ferulat tertinggi diperoleh pada daerah dengan warna hijau sangat tua pada titik waktu perendaman 9 jam dan waktu autoklaf 30 menit.
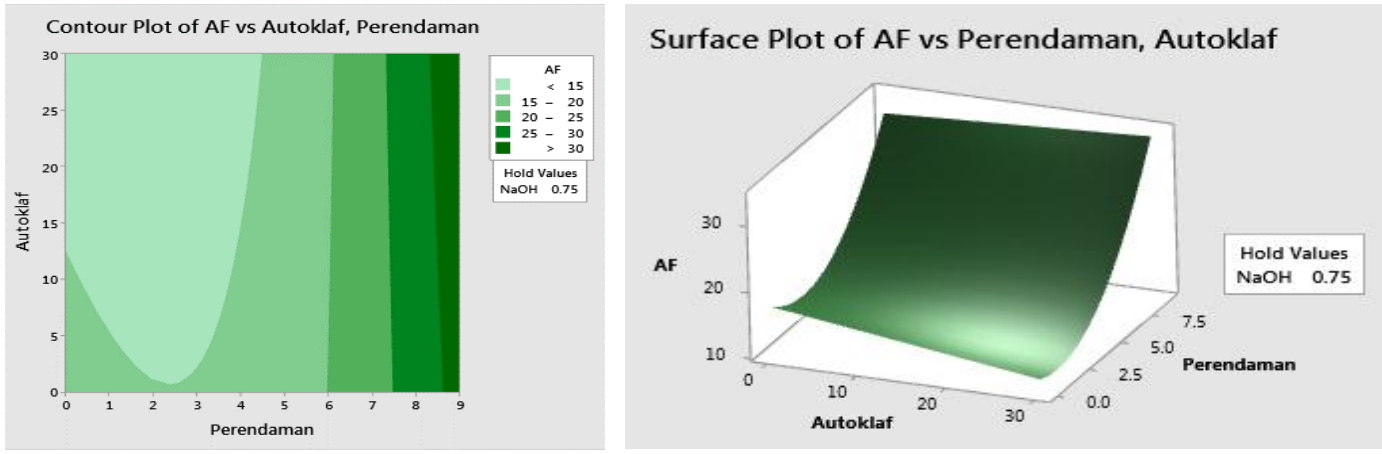

Gambar 6. Contour plot dan surface plot dari kadar asam ferulat, waktu perendaman dan waktu autoklaf

\section{Kondisi Optimal Menggunakan RSM}

Software Minitab 19 dapat menentukan kombinasi level-level variabel proses yang dapat menghasilkan respon yang optimal. Penentuan kombinasi level-level ini diperoleh proporsi setiap variabel $\mathrm{X}_{1}, \mathrm{X}_{2}$ dan $\mathrm{X}_{3}$ yang akan menghasilkan respon $\mathrm{Y}$ yang paling optimal. Gambar 7 menjelaskan proporsi untuk setiap variabel bebas yang akan menghasilkan variabel respon yang paling besar. Kondisi optimal diperoleh pada konsentrasi $\mathrm{NaOH}\left(\mathrm{X}_{1}\right) 1 \mathrm{M}$, waktu perendaman $\left(X_{2}\right) \quad 9$ jam dan waktu 
autoklaf $\left(X_{3}\right) 30$ menit yang menghasilkan $\mathrm{mg} / \mathrm{L}$. jumlah asam ferulat $(Y)$ sebesar 41,84

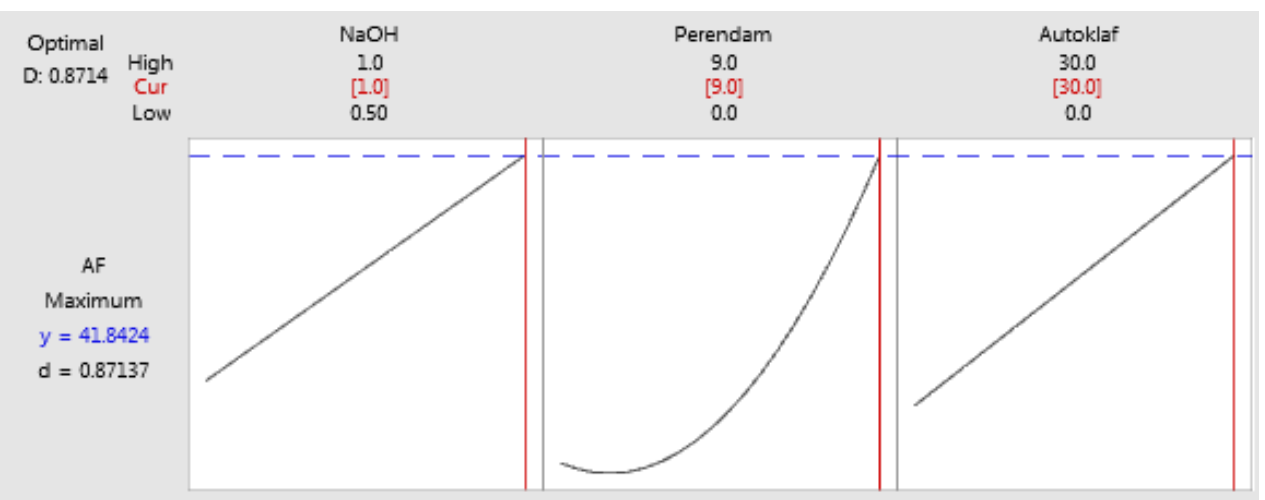

Gambar 7. Grafik optimum RSM pada ekstraksi asam ferulat dari serat mesokarp sawit

Dibandingkan dengan penelitian lainnya, proses ekstraksi dari serat TKKS menggunakan metode alkali $(\mathrm{NaOH})$ memperoleh kadar asam ferulat sebesar $62,52 \pm 6,24 \mathrm{mg} / \mathrm{L}$ (Aanifah et al., 2014). Sedangkan hasil penelitian Salleh et al. (2011) menyebutkan proses ekstraksi alkali $(\mathrm{NaOH})$ dari jerami padi dengan metode RSM dapat menghasilkan asam ferulat $5,18 \mathrm{mg} / \mathrm{g}$.

\section{Validasi Proses}

Validasi proses adalah percobaan tambahan yang dilakukan untuk mengetahui ketepatan prediksi yang diperoleh dari proses optimasi (Wahyono et al., 2018). Validasi dilakukan untuk menguji kebenaran data prediksi yang dihasilkan, maka dilakukan percobaan proses ekstraksi asam ferulat dari limbah serat mesokarp sawit dengan kondisi proses optimal sesuai prediksi yakni konsentrasi $\mathrm{NaOH} 1 \mathrm{M}$, waktu perendaman 9 jam dan waktu autoklaf 30 menit.

Tabel 4. Perbandingan Nilai Prediksi dengan Nilai Aktual Jumlah Asam Ferulat yang Diperoleh

\begin{tabular}{cccccc}
\hline \multirow{2}{*}{$\begin{array}{c}\text { Konsentrasi } \\
\mathrm{NaOH}\end{array}$} & $\begin{array}{c}\text { Waku } \\
\text { Perendaman }\end{array}$ & $\begin{array}{c}\text { Waktu } \\
\text { Autoklaf }\end{array}$ & \multicolumn{2}{c}{ Nilai Respon (mg/L) } & Akurasi (\%) \\
& & Prediksi & Aktual & \\
\hline $1 \mathrm{M}$ & 9 jam & 30 menit & 41,84 & 46,45 & 90,08 \\
\hline
\end{tabular}

\begin{abstract}
Percobaan validasi dengan kondisi operasi optimal sesuai prediksi menghasilkan asam ferulat sebesar 46,45 $\mathrm{mg} / \mathrm{L}$ (Tabel 4). Persentase akurasi model untuk memprediksi nilai asam ferulat yakni sebesar 90,08\%. Adapun selisih nilai hasil pemodelan dengan validasi dapat terjadi karena terdapat faktor lain di luar faktor yang digunakan yang mempengaruhi respon (Rucitra, 2014).
\end{abstract}

\section{SIMPULAN}

Dengan menggunakan metode permukaan respon (RSM) dapat ditentukan kondisi optimum proses ekstraksi asam ferulat dari limbah serat mesokarp sawit yakni pada konsentrasi $\mathrm{NaOH} 1 \mathrm{M}$, waktu perendaman 9 jam dan waktu autoklaf 30 menit. Prediksi jumlah asam ferulat yang terbentuk adalah 41,84 $\mathrm{mg} / \mathrm{L}$. Hasil validasi dengan percobaan pada kondisi optimum yang diprediksi, asam ferulat yang terbentuk sebesar 
$46,45 \mathrm{mg} / \mathrm{L}$. Hal ini menunjukan metode penentuan kondisi optimal dengan metode RSM ini memiliki nilai akurasi sebesar $90,08 \%$.

\section{DAFTAR PUSTAKA}

1. Aanifah, F.J.M., Yee, P.L., Wasoh, H. and Abd-Aziz, S. 2014 Effect of Different Alkaline Treatment on the Release of Ferulic Acid from Oil Palm Empty Fruit Bunch Fibres. J. Oil Palm Res. 26(4). pp.321-331.

2. Aarabi, A., Honarvar, M., Mizani, M., Faghihian, H. and Gerami, A. 2016. Extraction and Purification of Ferulic Acid as an Antioxidant from Sugar Beet Pulp by Alkaline Hydrolysis. Italian Journal of Food Science: 28, 362-375.

3. Badan Pusat Statistik. 2018. Statistik Kelapa Sawit Indonesia. Katalog: 5504003.

4. Deswati, H. S., Izzati, R., dan Hilfi, P. 2015. Optimasi Penentuan Kadmium dalam Air Laut secara Voltammetri Stripping Adsorptif dengan Metode Permukaan Respon (RSM). Prosiding SEMIRATA 2015 Bidang MIPA BKS-PTN Universitas Tanjungpura, Pontianak: 258267.

5. Hadrawi, J. 2014. Kandungan Lignin, Selulosa dan Hemiselulosa Limbah Baglog Jamur Tiram Putih (Pleurotus ostreatus) dengan Masa Inkubasi yang Berbeda sebagai Bahan Pakan Ternak. Skripsi. Fakultas Peternakan. Universitas Hasanuddin. Makassar.

6. Haryanti, A., Norsamsi, N., Sholiha, P.S.F. and Putri, N.P. 2014. Studi Pemanfaatan Limbah Padat Kelapa Sawit. Konversi. Vol. 3(2): 20-29.

7. Hasibuan, I. M. 2017. Optimasi Sterilisasi Buah Kelapa Sawit dengan Energi Gelombang Mikro: Faktor-Faktor yang Mempengaruhi Generasi Panas. Skripsi. Fakultas Teknik. Universitas Sumatera Utara.

8. Indonesia Eximbank. 2018. Analisa Rantai Pasok (Supply Chain) Komoditas Unggulan Ekspor Indonesia: Minyak Sawit.

9. Listyo, A.B., Kusrini, D. and Fachriah, E. 2018. Isolasi Asam Ferulat dari Daun Midi (Melia azedarach L.) dan Uji Aktivitas Antioksidan. Jurnal Kimia dan Pendidikan Kimia. Vol. 3 (1): 30-37.
10. Muchuweti, M., Zenda, G., Ndhlala, A.R. and Kasiyamhuru, A. 2005. Sugars, Organic Acid and Phenolic Compounds of Ziziphus mauritiana fruit. Eur. Food Res. Technol. 221: 570-574.

11. Nasruddin. 2012. Delignifikasi Tandan Kosong Kelapa Sawit Dilanjutkan dengan Hidrolisis Bertahap untuk Menghasilkan Glukosa. Jurnal Dinamika Penelitian Industri. Vol. 23(1): 1-11.

12. Nurmiah, S., Syarief, R., Sukarno, Peranginangin, R., dan Nurtama, B. 2013. Application of Response Surface Methodology in the Optimatization of Process Conditions of Alkali Treated Cottoni (ATC) Processing. Jurnal Pascapanen dan Bioteknologi 8(1): 9-22.

13. Rahardja, I. B. 2017. Perpindahan Panas Fiber Roof Building Kelapa Sawit (Elaeis guineensis Jacq.). Jurnal Citra Widya Edukasi Vol.IX (3): 229-238.

14. Rahmasita, M.E., Farid, M. and Ardhyananta, H. 2017. Analisa Morfologi Serat Tandan Kosong Kelapa Sawit sebagai Bahan Penguat Komposit Absorpsi Suara. Jurnal Teknis ITS 6(2): A584-A588.

15. Ratnawati, S.E., Ekantari, N., Pradipta, R.W. and Paramita, B.L. 2018. Aplikasi Response Surface Methodology (RSM) pada Optimasi Ekstraksi Kalsium Tulang Lele. Jurnal Perikanan Universitas Gadjah Mada Vol.20: 41-48.

16. Rucitra, R. 2014. Aplikasi Response Surface Method untuk Optimasi Proses Produksi Biodiesel Jarak Pagar Melalui Transesterifikasi In Situ. Skripsi. Institut Pertanian Bogor.

17. Salleh, N.H.M., Daud, M.Z.M., Arbain, D., Ahmad, M.S. and Ismail, K.S.K. 2011. Optimization of Alkaline Hydrolysis of Paddy Straw for Ferulic Acid Extraction. Industrial Crops and Products. 34: 16351640

18. Santoso, A. D. 2018. Evaluasi Kinerja Pabrik Kelapa Sawit dalam Produksi Energi Terbaharukan. Jurnal Teknologi Lingkungan 19(2): 213-220.

19. Silalahi, M. B. dan Supijatno. 2017. Pengelolaan Limbah Kelapa Sawit (Elaeis guineensis Jacq.) di Angsana Estate Kalimantan Selatan. Bul. Agrohorti 5(3): 373-383.

20. Sultan, F dan Soekamto, N.H. 2017. Sintesis Senyawa Fenetil 4-0-asetilferulat dari Asam 4-0-asetilferulat Melalui Reaksi 
Klorinasi dan Esterifikasi. Skripsi. Jurusan Kimia. Fakultas MIPA. Universitas Hasanudin. Makassar.

21. Susilo, Y. D. 2017. Kandungan Selulosa, Hemiselulosa dan Lignin Serat Sawit Hasil Fermentasi Jamur Pelapuk. Skripsi. Fakultas Peternakan. Universitas Hasanudin Makassar.

22. Tilay, A., Bule, M., Kishenkumar, J. and Annapure, U. 2008. Preparation of Ferulic Acid from Agricultural Wastes: Its Improved Extraction and Purification. Journal of Agricultural and Food Chemistry, 56, 7644-7648.

23. Trihaditia, R. 2015. Penentuan Formulasi Optimum pada Pembuatan Minuman Fungsional Rambut Jagung dengan Penambahan Madu dan Jeruk Nipis Menggunakan Metode RSM (Response Surface Method). Tesis. Fakultas Teknologi Pangan Universitas Pasundan. Bandung.

24. Wahyono, A., Kurniawati, E., Kasudjianingati, Park, K.H. dan Kang, W.W. 2018. Optimasi Proses Pembuatan Tepung Labu Kuning Menggunakan Response Surface Methodology untuk Meningkatkan Aktivitas Antioksidannya. J. Teknol. dan Industri Pangan 29(1): 29-38. 